\title{
Pleiotropic Effects of Flowering Time Genes in the Annual Crucifer Arabidopsis thaliana (Brassicaceae)
}

\author{
Peter H. Van Tienderen; Ibtisam Hammad; Frits C. Zwaal \\ American Journal of Botany, Vol. 83, No. 2. (Feb., 1996), pp. 169-174.
}

Stable URL:

http://links.jstor.org/sici?sici=0002-9122\%28199602\%2983\%3A2\%3C169\%3APEOFTG\%3E2.0.CO\%3B2-Q

American Journal of Botany is currently published by Botanical Society of America.

Your use of the JSTOR archive indicates your acceptance of JSTOR's Terms and Conditions of Use, available at http://www.jstor.org/about/terms.html. JSTOR's Terms and Conditions of Use provides, in part, that unless you have obtained prior permission, you may not download an entire issue of a journal or multiple copies of articles, and you may use content in the JSTOR archive only for your personal, non-commercial use.

Please contact the publisher regarding any further use of this work. Publisher contact information may be obtained at http://www.jstor.org/journals/botsam.html.

Each copy of any part of a JSTOR transmission must contain the same copyright notice that appears on the screen or printed page of such transmission.

The JSTOR Archive is a trusted digital repository providing for long-term preservation and access to leading academic journals and scholarly literature from around the world. The Archive is supported by libraries, scholarly societies, publishers, and foundations. It is an initiative of JSTOR, a not-for-profit organization with a mission to help the scholarly community take advantage of advances in technology. For more information regarding JSTOR, please contact support@jstor.org. 


\title{
Pleiotropic effects of flowering time Genes in THE ANNUAL CRUCIFER ARABIDOPSIS THALIANA (BRASSICACEAE $)^{1}$
}

\author{
Peter H. van Tienderen, ${ }^{2}$ Ibtisam Hammad, ${ }^{3}$ And Frits C. ZwaAl \\ Netherlands Institute of Ecology, P.O. Box 40, 6666 ZG Heteren, The Netherlands
}

\begin{abstract}
Variation in flowering time of Arabidopsis thaliana was studied in an experiment with mutant lines. The pleiotropic effects of flowering time genes on morphology and reproductive yield were assessed under three levels of nutrient supply. At all nutrient levels flowering time and number of rosette leaves at flowering varied among mutant lines. The relationship between these two traits depended strongly on nutrient supply. A lower nutrient supply first led to an extension of the vegetative phase, while the mean number of leaves at flowering was hardly affected. A further reduction resulted in no further extension of the vegetative phase and, on average, plants started flowering with a lower leaf number. At low nutrients, early flowering affected the timing of production of siliques rather than the total output, whereas late flowering was favorable at high nutrients. This may explain the fact that many plant species flower at a relatively small size under poor conditions. Flowering time genes had pleiotropic effects on the leaf length, number of rosette and cauline leaves, and number of axillary flowering shoots of the main inflorescence. Silique production was positively correlated with the number of axillary shoots of the main inflorescence; the number of axillary primordia appeared to have a large impact on reproductive yield.
\end{abstract}

Key words: Arabidopsis thaliana; flowering time; phenotypic plasticity; pleiotropy.

The optimal allocation of resources toward growth or reproduction has been the subject of many theoretical and empirical studies (e.g., Cohen, 1971; Pemadasa and Lovell, 1976; Chiarello and Roughgarden, 1984; Klinkhamer et al., 1992). The reasoning behind the theoretical models is usually as follows. Flowering early, at a small vegetative size, implies that limited resources can be allocated to reproduction, which results in a low reproductive output. Later flowering at a larger vegetative size may allow a higher reproductive output, but only if sufficient resources remain available during seed set and if given enough time to complete the reproductive cycle. Conditions for growth may become poorer over time, for instance due to depletion of nutrients, drought, or increased competition with the surrounding vegetation (Cohen, 1971). Under such conditions, timing of reproduction will be under stabilizing selection, but with an optimal timing that may depend on environmental factors such as resource availability and season length.

These models rest heavily on assumptions concerning the effects of the transition from vegetative growth to reproduction. In plants, reproductive organs (e.g., stalks, bracts, siliques) are often photosynthetically active and may to a large part be self-supporting (e.g., Reekie and Bazzaz, 1987). It is by no means certain that an early shift to reproduction always leads to a smaller plant and hence a smaller reproductive output. It is therefore important to study the consequences of variation in flowering time. There is increasing evidence that variation in

\footnotetext{
${ }^{1}$ Manuscript received 24 January 1995; revision accepted 20 June 1995.

The authors thank A. van Hinsberg, M. Koornneef, J. A. Shykoff, and $J$. van der Veen for valuable suggestions to improve this manuscript. Publication 2019, Netherlands Institute of Ecology, Centre for Terrestrial Ecology.

${ }^{2}$ Author for correspondence (e-mail: TIENDEREN@NIOO.NL).

${ }^{3}$ Current address: Mansoura University, Faculty of Science, Department of Botany, Egypt.
}

flowering time is affected by major genes. In Arabidopsis thaliana, a single dominant late-flowering allele (at the FRI locus) appeared to cause the major differences between plants collected in different geographic areas (Lee, Bleecker, and Amasino, 1993; Clarke and Dean, 1994) but also on a local scale (I. Hammad and P. H. van Tienderen, unpublished data). Variation in natural populations may be due to variation in a fairly small number of loci (Karlovská, 1974; Napp-Zinn, 1985). In contrast, many loci affecting flowering time were discovered using mutagenesis (Koornneef, Hanhart, and van der Veen, 1991). As yet, little is known of the pleiotropic effects of genes that cause flowering time variation (e.g., on reproductive yield). In Phaseolus vulgaris a single photoperiod gene affected 26 traits, including traits involving resource partitioning in time, or involving morphological and meristem development (Wallace et al., 1993). Pleiotropy can be an important cause of genetic correlations among traits, and may strongly affect the outcome of selection (Lande and Arnold, 1983); furthermore, selection on any trait can be seen as a result of a genetic correlation between the trait and fitness, as stated by the Secondary Theorem of Natural Selection (Robertson, 1966; cf. Rausher, 1992; Van Tienderen and de Jong, 1994).

In this paper, the flowering behavior of Arabidopsis thaliana (thale cress) is investigated. A. thaliana is largely self-pollinated and heterozygotes are seldom observed in natural populations (Jones, 1971a; Abbott and Gomes, 1989). This implies that selection in natural populations mainly concerns selection among homozygous lineages (Jones, 1971b), and wrong timing may mean the extinction of the lineage unless recovery from the seed bank is possible. Most ecotypes are winter annuals: germination occurs in autumn, the small rosette bolts early the next spring, and plants die after flowering and seed set (Rédei, 1969; Grime, Hodgson, and Hunt, 1988). Variation in flowering time has been generated by mutagenesis in ho- 
mozygous races (Hussein, 1968; Větřilová, 1973; NappZinn, 1987; Koornneef, Hanhart, and van der Veen, 1991). We compare five homozygous mutant lines and the ancestral wild type, and address the following questions: What is the relationship between plant size and flowering time? How does this relationship depend on nutrient supply? What are the consequences of flowering time variation for seed production of plants under various nutrient conditions? The use of monogenic mutant lines offers a direct assessment of the pleiotropic effects of single genes that affect flowering in an otherwise identical genetic background.

\section{MATERIALS AND METHODS}

Study species-A. thaliana is a self-pollinated, annual crucifer, extensively used in molecular genetic studies because of its short generation time and small genome size. It is a quantitative long-day plant that will eventually flower under almost any photoperiod; for some ecotypes flowering is greatly accelerated by exposure to low temperatures (vernalization) (Jones, 1971c; Napp-Zinn, 1987; Bagnall, 1992; Karlsson, Sills, and Nienhuis, 1993). Seeds of A. thaliana race Landsberg erecta (Rédei, 1992) and five derived monogenic late-flowering mutant lines were obtained from M. Koornneef (Agricultural University, Wageningen). The mutant lines were generated by treating seeds with EMS (ethylmethane sulfonate) or radiation. The wild type flowers early, and requires long days but no vernalization. The mutant lines were selected because they were physiologically characterized (Martinez-Zapater and Somerville, 1990; Koornneef, Hanhart, and van der Veen, 1991) and the map positions of the mutations were determined (Koornneef, Hanhart, and van der Veen, 1991). Moreover, they represent three different categories of late-flowering genes, so that, potentially, they may have different pleiotropic effects on other traits: (1) mutant $f_{c a-1}$ reacts strongly to day length and vernalization, (2) mutants fe-l and fwa-l react to day length but hardly to vernalization, and (3) $\mathrm{co}-3$ and gi-3 do not react to either day length or vernalization. Mutant fwa-1 is dominant, co-3 is intermediate, and the others are recessive (Koornneef, Hanhart, and van der Veen, 1991).

Experimental conditions-Seeds were imbibed in petri dishes with filter paper moistened with demi-water, and placed at $5^{\circ} \mathrm{C}$ for $3 \mathrm{~d}$. After this cold treatment to break dormancy, petri dishes were placed in a germination cabinet $\left(15 / 24^{\circ} \mathrm{C}, 10 / 14 \mathrm{~h}\right.$ night/day cycle). Four days later germinated seeds were transferred to pots $(9 \times 9 \times 10 \mathrm{~cm})$ filled with river sand and covered with aluminium foil to prevent algal growth. Pots were placed in the greenhouse under natural light on 15 March 1992, in a fully randomized design with ten replicates per line per treatment. Day length (time from sunrise to sunset) increased from $12.05 \mathrm{~h}$ on $15 \mathrm{March}$, to $16.14 \mathrm{~h}$ on $7 \mathrm{July}$, at harvest. Nutrients were applied by flushing the pots weekly with a Hoagland's solution of 1, 5, or $25 \%$ strength. The highest concentration caused a lower success rate of transfer from petri dishes to the pots of the tiny seedlings, probably due to the shift from demi-water in the petri dishes to the high nutrient concentrations in the pots; however, successful seedlings grew well. Phenological and morphological measures were taken: flowering time, number of rosette leaves, and length of longest rosette leaf at flowering were recorded, and the number of ripe siliques was determined for three periods (before 1 June, from 1 to 17 June and from 17 June to 7 July). The length of the main inflorescence, the number of cauline leaves and of axillary flowering shoots were recorded at harvest, when flowering had ceased and almost all siliques had ripened.

Statistical analyses-Morphological traits were analyzed by analysis of variance (MANOVA procedure, SPSS). Rank transformation was employed to reduce the heterogeneity of variances (Potvin and Roff, 1993). Line effects were broken down into variation due to the contrast

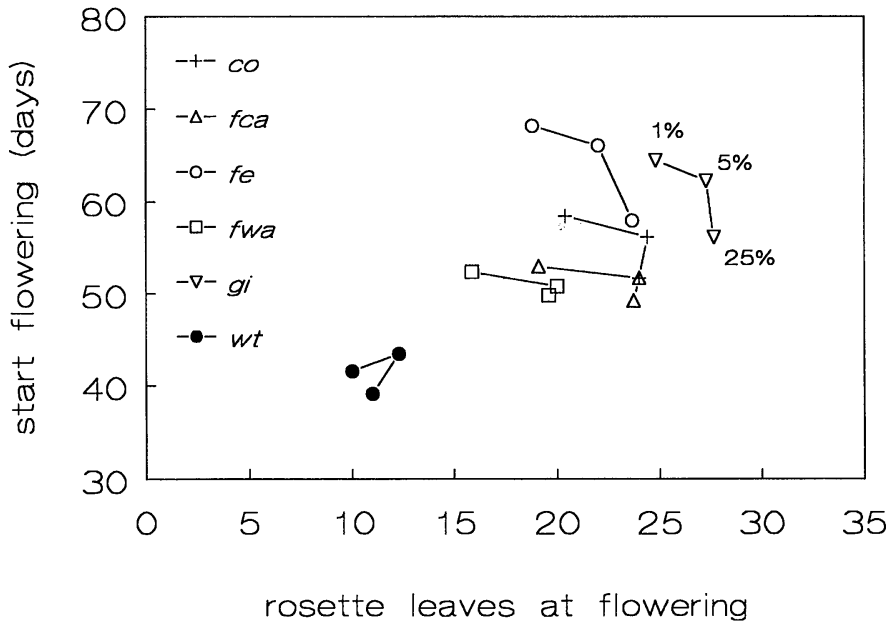

Fig. 1. Relationship between number of rosette leaves at flowering and flowering time, of Arabidopsis thaliana race Landsberg erecta wild type (wt) and five derived mutant lines, at three nutrient levels. For all lines, the relative positions of the three treatments was as indicated for $g i$, i.e., clockwise from 1 to 5 to $25 \%$ of Hoagland's solution.

of wild type vs. late-flowering mutants $(\mathrm{df}=1)$, and among the late flowering mutants $(\mathrm{df}=4)$. In addition to a global test for differences among nutrient treatments, two nonorthogonal contrasts were made between the lower ( 1 vs. $5 \%$ ) and higher (5 vs. $25 \%$ ) levels. Silique production over the three periods was analyzed by multivariate ANOVA, with period a within-subject factor (MANOVA procedure, SPSS).

\section{RESULTS}

Age and size at reproduction-Mutant lines flowered 10-25 d later than the wild type (Fig. 1). A longer period of vegetative growth resulted in more rosette leaves for the late-flowering mutants (Table 1; Fig. 1). Line $f e$ had a lower success rate of transfer from petri dishes to pots, and produced leaves at a lower rate than the other lines, a difference not observed in earlier studies (MartinezZapater and Somerville, 1990; Koornneef, Hanhart, and van der Veen, 1991; Bagnall, 1993); it is unknown what caused this difference, possibly the quality of the seed batch was involved.

The nutrient supply affected both the time of flowering and the number of leaves at flowering (Fig. 1; Table 1). On average, the mutant lines flowered after $52.7 \mathrm{~d}$ with 23.6 leaves at $25 \%$ nutrients, after $57.0 \mathrm{~d}$ with 23.6 leaves at $5 \%$, and after $58.4 \mathrm{~d}$ with only 19.8 leaves at $1 \%$ nutrients. Thus, a reduction from high to intermediate nutrient supply extended the vegetative phase without altering the number of leaves. However, reducing nutrients from intermediate to low levels caused no further extension of the vegetative phase, and flowering started at about the same age with a lower number of leaves (Table 1). This same trend was found in all mutant lines, although lines differed in mean time of flowering and leaf number (Fig. 1).

To evaluate the consequences of variation in flowering time for fecundity, silique production was measured in three consecutive periods (Table 2). At the lowest nutrient levels, the wild type produced as many siliques as the other types (Fig. 2A; Table 2); at the intermediate nutrient level mutant lines produced somewhat more siliques (Fig. 
TABLE 1. Statistical differences in morphological traits among six lines of Arabidopsis thaliana, grown at three nutrient levels. Traits were rank transformed prior to analyses. All effects tested against the within-group error MS with df $=227$ (last column). Other tabulated values are $F$ ratios. In parentheses: hypothesis and error degrees of freedom. Line effects were broken down into a difference between the wild type and the mutant lines and differences among the five mutant lines. For the effects of nutrients, a global test as well as contrasts between adjacent levels are presented.

\begin{tabular}{|c|c|c|c|c|c|c|c|}
\hline & \multicolumn{2}{|c|}{ Line effects } & \multicolumn{3}{|c|}{ Nutrient effects } & \multirow{2}{*}{$\begin{array}{c}\text { Interaction } \\
\text { Line } \times \\
\text { nutrient } \\
(10,227)\end{array}$} & \multirow[b]{2}{*}{ Error MS } \\
\hline & $\begin{array}{c}\text { Wild type } \\
\text { vs. mutants } \\
(1,227)\end{array}$ & $\begin{array}{c}\text { Among mutant } \\
\text { lines } \\
(4,227)\end{array}$ & $\begin{array}{l}\text { Total effect } \\
(2,227)\end{array}$ & $\begin{array}{l}\text { Contrast } \\
1 \text { vs.5\% } \\
(1,227)\end{array}$ & $\begin{array}{c}\text { Contrast } \\
5 \text { vs. } 25 \% \\
(1,227)\end{array}$ & & \\
\hline Flowering time & $288.9 * * *$ & $63.5^{* * *}$ & $20.3 * * *$ & $4.3^{*}$ & $21.7 * * *$ & 1.4 & 1381.3 \\
\hline Number of rosette leaves & $510.6^{* * *}$ & $68.9 * * *$ & $76.3 * * *$ & $122.4 * * *$ & 0.3 & $3.8 * * *$ & 944.5 \\
\hline Length rosette leaf & $35.9^{* * *}$ & $6.2 * * *$ & $458.7 * * *$ & $500.2 * * *$ & $91.4 * * *$ & 1.7 & 973.7 \\
\hline Inflorescence length & $28.6 * * *$ & $20.3 * * *$ & $581.8 * * *$ & $623.3 * * *$ & $122.9 * * *$ & $4.4 * * *$ & 745.8 \\
\hline Number of cauline leaves & $294.8 * * *$ & $14.2 * * *$ & $102.1 * * *$ & $109.4 * * *$ & $21.5 * * *$ & $3.4 * * *$ & 1433.3 \\
\hline \multicolumn{8}{|l|}{ Number of axillary } \\
\hline flowering shoots & $147.1 * * *$ & 0.7 & $150.7 * * *$ & $137.5 * * *$ & $47.9 * * *$ & $7.8 * * *$ & 1532.7 \\
\hline
\end{tabular}

*** $P<0.001 ; * * P<0.01 ; * P<0.05$.

2B; Table 2), and at the highest nutrient level the wild type was surpassed by all late-flowering mutant lines (Fig. 2C; Table 2). At the highest nutrient level the mutant lines that flowered intermediately (notably co) had the highest silique production (Fig. 2C). Perhaps surprisingly, at low nutrient levels early flowering inferred no costs in terms of a reduced total silique production. Observed differences were not so much in the total number of siliques, as in the moment when they were produced. The silique production in the first period was highest for the early-flowering wild type (Fig. 2, closed bars), with only one exception ( $f c a$ at $25 \%$, Fig. 2C). Late-flowering plants also started to produce ripe siliques later and consequently strong line $\times$ period interactions were found for silique production at all three treatment levels. The temporal pattern of silique production of the wild type differed from that of the mutant lines (Table 2, L1 $\times$ period interaction). The wild type showed a decreasing production of siliques over time, whereas the mutant lines showed an increase over time (Fig. 2), allowing them to

TABLE 2. Statistical analysis of the production of siliques. Differences among lines are broken down into the difference between the wild type and the mutant lines (L1) and differences among mutant lines (L2). The silique production of each plant was measured in three consecutive periods. Therefore, Period and line $\times$ period interactions were tested as within-plant factors, by comparing the $F$ approximation for the multivariate Pillais' $\lambda$ with the appropriate critical value. In parentheses: hypothesis and error df.

\begin{tabular}{|c|c|c|c|}
\hline & \multicolumn{3}{|c|}{ Nutrient treatment } \\
\hline & $1 \%$ & $5 \%$ & $25 \%$ \\
\hline \multicolumn{4}{|l|}{ Between-plant effects } \\
\hline $\begin{array}{l}F \text { ratio for difference of } \\
\text { wild type vs. mutants (L1) }\end{array}$ & $\begin{array}{c}3.9 \\
(1,92)\end{array}$ & $\begin{array}{c}4.1^{*} \\
(1,91)\end{array}$ & $\begin{array}{l}13.9 * * \\
(1,45)\end{array}$ \\
\hline $\begin{array}{l}F \text { ratio for differences } \\
\text { among mutants (L2) }\end{array}$ & $\begin{array}{l}5.0^{* *} \\
(4,92)\end{array}$ & $\begin{array}{l}23.2 * * * \\
(4,91)\end{array}$ & $\begin{array}{l}9.4 * * * \\
(4,45)\end{array}$ \\
\hline Error MS & 37.7 & 191.9 & 8711.0 \\
\hline \multicolumn{4}{|l|}{$F$ ratios for within-plant effects } \\
\hline Period & $\begin{array}{c}102.2 * * * \\
(2,91)\end{array}$ & $\begin{array}{l}60.8 * * * \\
(2,90)\end{array}$ & $\begin{array}{l}15.1 * * * \\
(2,44)\end{array}$ \\
\hline $\mathrm{L} 1 \times$ period & $\begin{array}{l}57.4 * * * \\
(2,91)\end{array}$ & $\begin{array}{l}41.0 * * * \\
(2,90)\end{array}$ & $\begin{array}{l}9.9 * * * \\
(2,44)\end{array}$ \\
\hline $\mathrm{L} 2 \times$ period & $\begin{array}{l}17.1 * * * \\
(8,184)\end{array}$ & $\begin{array}{l}9.4 * * * \\
(8,182)\end{array}$ & $\begin{array}{l}6.4 * * * \\
(8,90)\end{array}$ \\
\hline
\end{tabular}

*** $P<0.001$; ** $P<0.01$; * $P<0.05$. catch up with, or even surpass the wild type in total silique production.

Pleiotropic effects of flowering time-Length of rosette leaves at flowering was also strongly affected by nutrient level (Table 1). The nutrient $\times$ line interaction of rank-transformed leaf lengths was not significant $(P=$ 0.07, Table 1), despite the apparent differences among mutant lines at the highest nutrients level (Fig. 3A). Inflorescence length, number of cauline leaves, and number of axillary branches of the main inflorescence all showed highly significant line and treatment effects (Table 1). The wild type's inflorescence differed in length from the mean of the mutant lines (Table 1), but it was not consistently longer or shorter (Fig. 3B). The development of the shoot apical meristem followed a fixed pattern, in agreement with the description of Hempel and Feldman (1994). At a certain time, the apical meristem switched from producing leaf primordia that develop into cauline leaves, to the production of flower primordia that develop into flowers. Axillary flowering shoots (paraclades) may develop from the buds in the axils of the cauline leaves. The potential number of axillary shoots is fixed relatively early in development, before the first flower opens, although their actual development occurs after flowers are formed by the shoot apical meristem (Hempel and Feldman, 1994). Branching increases the number of independent meristems that produce flowers. It appeared that if flowering started with a small vegetative rosette, fewer leaf primordia were formed and that therefore the potential production of side branches and new reproductive meristems was restricted. The apical flowering stem of the wild type produced fewer cauline leaves (Fig. 3C) and fewer axillary flowering shoots (Fig. 3D). Furthermore, lower nutrient levels also resulted in fewer cauline leaves and axillary shoots in the mutant lines (Fig. 3C, D).

The number of axillary flowering shoots was positively correlated with the production of siliques: $r=0.40(N=$ 97, $P<0.001), r=0.31(N=97, P<0.01)$, and $r=$ $0.51(N=50, P<0.001)$ for the 1,5 , and $25 \%$ nutrient treatments, respectively, all lines combined. We also looked at the variation in silique production explained by five morphological traits together (number and length of rosette leaves, inflorescence length, number of cauline 

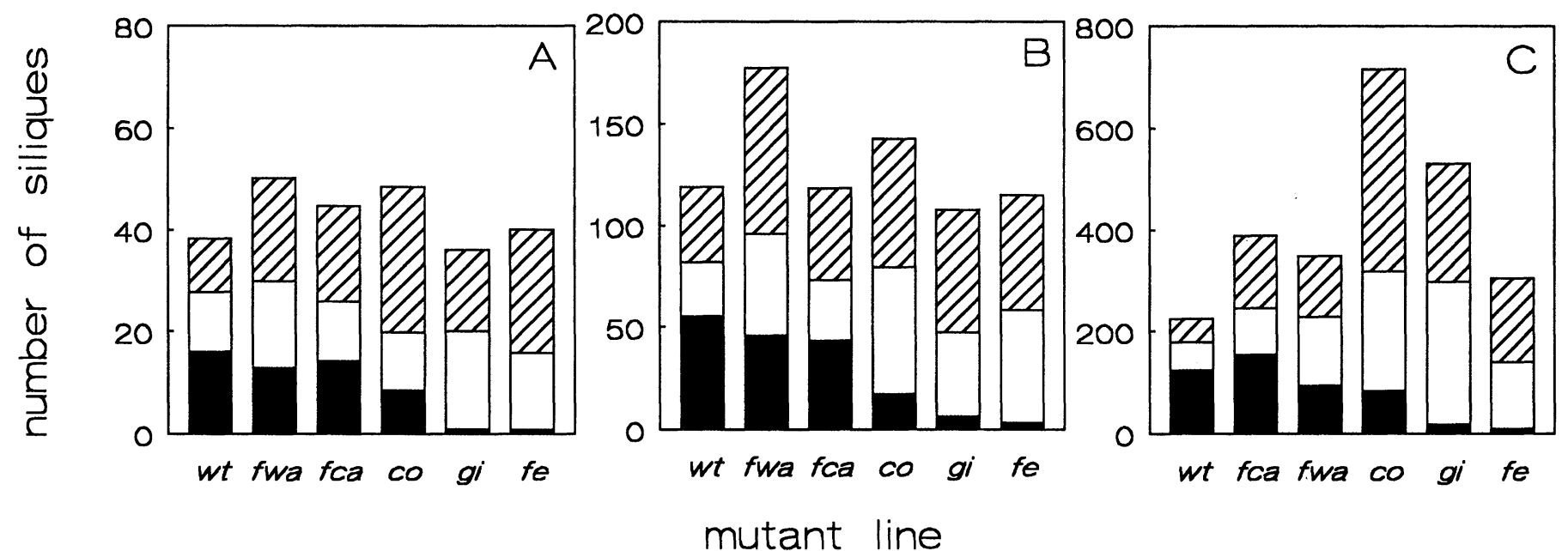

Fig. 2. Cumulative production of siliques of six lines of Arabidopsis thaliana in three periods: before 1 June (lower, closed part of bar), from 1 to 17 June (middle, open part), and from 17 June to 7 July (upper, hatched part); three nutrient levels were applied (A) $1 \%$, (B) 5\%, and (C) $25 \%$ of Hoagland's solution, applied weekly. Mutant lines are ordered from early to late, based on the mean flowering time within each treatment.

leaves, and axillary shoots). Multiple regression of silique production on these traits explained 34.9, 23.3, and $54.8 \%$ of the total variation in silique production for the 1,5 , and $25 \%$ nutrient treatments, respectively. The number of axillary shoots alone explained 15.8, 9.6, and $26.5 \%$ of the variation in silique production, respectively. Thus, an important portion of the variation explained by five traits could also be explained by the number of axillary shoots only, i.e., 45,42 , and $48 \%$ for the three treatments, respectively. Variation in flowering time apparently affected further meristem development, which in turn affected the subsequent production of siliques.
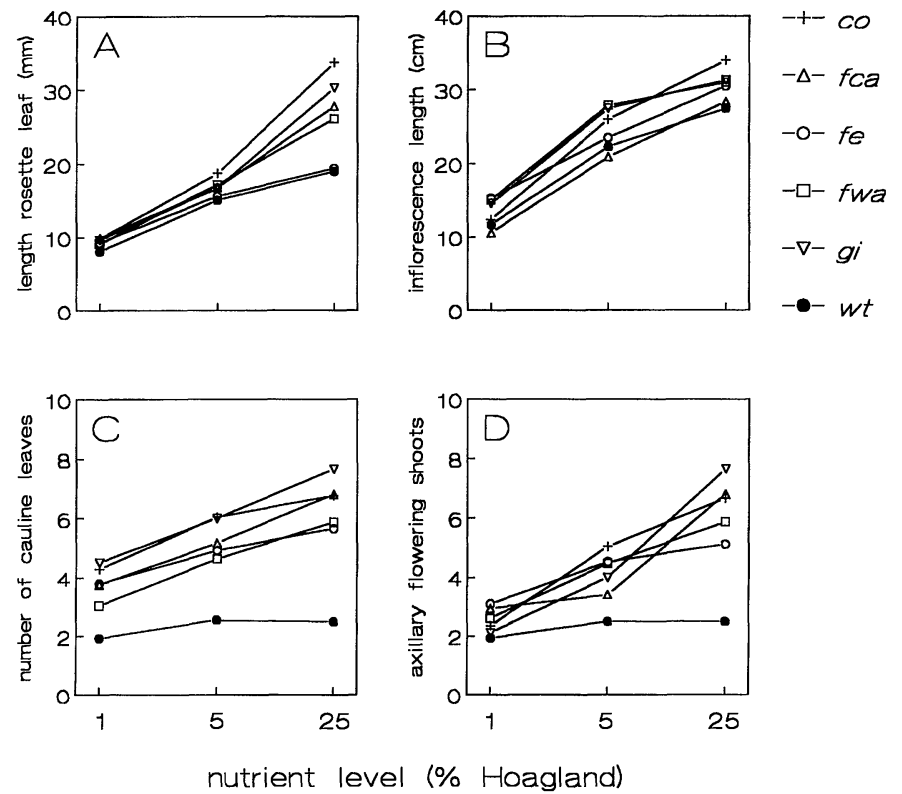

Fig. 3. Reaction of six Arabidopsis thaliana lines to variation in nutrient levels. (A) Length of longest rosette leaf. (B) Total length of main inflorescence. (C) Number of cauline leaves on the main inflorescence. (D) Number of axillary branches of the main inflorescence.

\section{DISCUSSION}

The use of mutant lines to study questions in evolutionary ecology is relatively rare. The genetic background of variation in morphological and life history traits, and their plasticities, is currently widely debated (Barton and Turelli, 1989; Orr and Coyne, 1992; Via et al., 1995; Schlichting and Pigliucci, 1995). In Arabidopsis, there is increasing evidence that major genes are responsible for ecotypic variation in flowering time (Lee, Bleecker, and Amasino, 1993; Clarke and Dean, 1994). Jones (1971c) suggested that early flowering would allow a population to reproduce twice per year, whereas late flowering would make plants strictly annual under natural conditions. We found similar differences among Dutch populations, and an analysis of the $F_{2}$ 's of crosses between early and late plants indicated that a single major gene was responsible for this difference (I. Hammad and P. H. van Tienderen, unpublished data). Although genes with small effects on flowering time are also found (Westerman, 1971; Karlovská, 1974), it appears that differences in flowering behavior are often caused by the presence of one or a few major genes. If so, it becomes relevant to study the pleiotropic effects of such genes in different genetic backgrounds and under various environmental conditions. Also, evolutionary change may not depend on changes in the frequencies of genes with small effects that are present in most populations; instead, evolutionary change may depend on the occurrence (by mutation or immigration) of particular genes that change the flowering behavior dramatically. The role of genes with smaller effects could be fine-tuning of the flowering response after such a major gene becomes established. The current study demonstrated that single-gene differences in an otherwise identical genetic background were responsible for changes in the plant size at flowering, meristem development of the inflorescence, total silique production, and the timing of silique production. Furthermore, their effects on silique production were affected by nutrient supply, so that in the field the adaptive value of variation in 
flowering time may depend strongly on environmental conditions.

Reactions of flowering time on environmental conditions may serve to postpone reproduction until the suitable season; ecotypes from a latitudinal or altitudinal gradient often show marked differences in their reactions (Laibach, 1951; Rédei, 1969). Many studies have demonstrated genetic variation between ecotypes in flowering in response to photoperiod, vernalization, and red/far-red ratio (see Rédei, 1969; Jones, 1971c; Bagnall, 1992, 1993; Karlsson, Sills, and Nienhuis, 1993). Genotype $\times$ environment interactions were also found (Westerman, 1971). The reactions of flowering time to nutrient supply are superimposed on these reactions related to seasonal clues. Different late-flowering genotypes reacted remarkably similarly to nutrient supply. Within the genetically uniform mutant lines, plants flowered when, on average, a certain number of leaves was attained. This number of leaves appeared to be specific for each mutant, and plants reacted to a higher or lower nutrient supply by decreasing or extending the period of vegetative growth. However, under poor conditions, plants started to flower well before this number of leaves was reached. The different classes of mutant lines (Koornneef, Hanhart, and van der Veen, 1991; see Materials and Methods) showed similar responses to nutrient supply, despite their large differences in flowering time, and different underlying physiological mechanisms. A similar trend was observed in natural populations by Zhang and Lechowicz (1994); they observed only a slight delay of flowering under nutrientpoor conditions, and no nutrient $\times$ population interaction.

Flowering time and the size of the rosette at flowering affects further development and seed production. Aarssen and Clauss (1992) showed that potential seed production increased with plant size in a density series; in their experiment plants were harvested after ripening of the first siliques. In our study, however, plants were able to continue flowering. Flowering early at a low nutrient supply resulted in earlier silique production, but total yield was hardly affected by timing of the initiation of flowering. Clearly, the outcome of selection given such circumstances in the field strongly depends on the season length. For instance, in Arabidopsis, drought may terminate the growing season in ruderal sandy sites. However, the disadvantage of flowering early under low nutrients may be limited given the small differences in total yield we observed between early and late lines, whereas there certainly is a risk to flowering late. This suggests that poor conditions may select for flowering early at a small size, which may explain the frequent occurrence of very small flowering plants in the field. The flowering stems and their cauline leaves can be largely self-supporting as shown by plants continuing to produce flowers under low nutrients after the leaves of the main rosette had died.

Under high nutrient supply the situation was different. Again, early flowering led to an earlier production of siliques, and in the field early flowering could be advantageous in short seasons. However, later flowering genotypes quickly caught up, and surpassed the early-flowering wild type. Plants with a larger rosette at flowering may have had more resources to spend on reproduction. A larger rosette also produced an inflorescence with more cauline leaves and primordia for axillary shoots. If these primordia develop into flowering shoots, the potential flower and silique production is greatly enhanced. Under low nutrients the early-flowering line produced about as many axillary shoots as the late-flowering lines, and did not produce fewer siliques. Under high nutrients the lateflowering lines made many more shoots, allowing a rapid rate of flower and silique production. In an experiment with natural populations, the effects of a delay of flowering on flower production was highest under nutrientrich conditions (27.9 vs. 2.7 flowers extra per day of delay of flowering for nutrient rich and poor conditions, respectively; Zhang and Lechowicz, 1994). Although data on meristem production were not presented, it is clear that a daily rate of almost 28 flowers required many active independent flowering meristems.

Flowering time is determined by a shift in the partitioning of resources between reproductive and vegetative growth (Wallace et al., 1993). In Arabidopsis, the apical meristem is dedicated to formation of the inflorescence, in contrast with species with an indeterminate development such as beans (Wallace et al., 1993). The development of the main rosette ceases at flowering, and vegetative growth continues by the formation of cauline leaves. However, since the potential number of axillary meristems is fixed early in development (Hempel and Feldman, 1994), it appears that both allocation of resources and availability of sinks as mediated by meristem development are important for final reproductive yield (Watson and Casper, 1984). It is likely that silique production does not depend on available resources only, but can also be constrained by the availability of suitable meristems, as was shown for Eichhornia paniculata (Watson, 1984). This may be particularly important when conditions change between the moment of meristem formation and their further development into flowering stems. Such effects may need to be considered in models that aim to predict optimal growth schedules of plants.

\section{LITERATURE CITED}

Aarssen, L. W., And M. J. Clauss. 1992. Genotypic variation in fecundity allocation in Arabidopsis thaliana. Journal of Ecology 80: $109-114$.

AвbotT, R. J., AND M. F. Gomes. 1989. Population genetic structure and outcrossing rate of Arabidopsis thaliana (L.) Heynh. Heredity 62: $411-418$.

Bagnall, D. J. 1992. Control of flowering in Arabidopsis thaliana by light, vernalisation and gibberellins. Australian Journal of Plant Physiology 19: 401-409.

1993. Light quality and vernalization interact in controlling late flowering in Arabidopsis ecotypes and mutants. Annals of Botany 71: 75-83.

Barton, N. H., AND M. Turelli. 1989. Evolutionary quantitative genetics: how little do we know. Annual Review of Genetics 23: 337 370 .

Chiarello, N., and J. Roughgarden. 1984. Storage allocation in seasonal races of an annual plant: optimal versus actual allocation. Ecology 65: 1290-1301.

Clarke, J. H., AND C. DeAN. 1994. Mapping FRI, a locus controlling flowering time and vernalization response in Arabidopsis thaliana. Molecular and General Genetics 242: 81-89.

CoHEN, D. 1971. Maximizing final yield when growth is limited by time or by limiting resources. Journal of Theoretical Biology 33: 299-307.

Grime, J. P., J. G. Hodgson, And R. Hunt. 1988. Comparative plant ecology: a functional approach to common British species. Unwin Hyman, London. 
Hempel, F. D., AND L. J Feldman. 1994. Bi-directional inflorescence development in Arabidopsis thaliana: acropetal initiation of flowers and basipetal initiation of paraclades. Planta 192: 276-286.

HusseIN, H. A. S. 1968. Genetic analysis of mutagen-induced flowering time variation in Arabidopsis thaliana (L.) Heynh. Ph.D. dissertation, Agricultural University. Wageningen, The Netherlands.

JONES, M. E. 1971a. The population genetics of Arabidopsis thaliana. I. The breeding system. Heredity 27: 39-50.

- 1971b. The population genetics of Arabidopsis thaliana. II. Population structure. Heredity 27: 51-58.

- 1971c. The population genetics of Arabidopsis thaliana. III The effect of vernalisation. Heredity 27: 59-72.

KARLOVSKÁ, V. 1974. Genotypic control of the speed of development in Arabidopsis thaliana (L.) Heynh. lines obtained from natural populations. Biologia Plantarum (Praha) 16: 107-117.

Karlsson, B. H., G. R. Sills, AND J. Nienhuis. 1993. Effects of photoperiod and vernalization on the number of leaves at flowering in 32 Arabidopsis thaliana (Brassicaceae) ecotypes. American Journal of Botany 80: 646-648.

Klinkhamer, P. G. L., E. Meelis, T. J. De Jong, and J. Weiner. 1992. On the analysis of size-dependent reproductive output in plants. Functional Ecology 6: 308-316.

Koornneef, M., C. J. Hanhart, and J. H. van der Veen. 1991. A genetic and physiological analysis of late flowering mutants in $\mathrm{Ar}$ abidopsis thaliana. Molecular and General Genetics 229: 57-66.

LAIBACH, F. 1951. Über sommer- und winterannuelle Rassen von $\mathrm{Ar}$ abidopsis thaliana (L.) Heynh. Ein Beitrag zur Ätiologie der Blütenbildung. Beiträge zur Biologie der Pflanzen 28: 173-210.

LANDE, R., AND S. J. ARNOLD. 1983. The measurement of selection on correlated characters. Evolution 37: 1210-1226.

LeE I., A. BleECKER, AND R. AmAsino. 1993. Analysis of naturally occurring late flowering in Arabidopsis thaliana. Molecular and General Genetics 237: 171-176.

MartineZ-Zapater, J. M., AND C. R. Somerville. 1990. Effect of light quality and vernalization of late flowering mutants of Arabidopsis thaliana. Plant Physiology 92: 770-776.

NAPP-ZinN, K. 1985. Arabidopsis thaliana. In H. A. Halevy [ed.], Handbook of flowering, vol. 1, 492-503. CRC Press, Boca Raton FL.

- 1987. Vernalization-environmental and genetic regulation. In J. G. Atherton [ed.], Manipulation of flowering, 123-132. Butterworth, London.

ORR, H. A., AND J. A. CoYNe. 1992. The genetics of adaptation: a reassessment. American Naturalist 140: 725-742.

Pemadasa, M. A., AND P. H. Lovell. 1976. Effects of the timing of the life cycle on the vegetative growth of some dune annuals. Journal of Ecology 64: 213-222.

Potvin, C., AND D. A. RoFf. 1993. Distribution-free and robust statistical methods: viable alternatives to parametric statistics? Ecology 74: $1617-1628$.

RAUSHER, M. D. 1992. The measurement of selection on quantitative traits: biases due to environmental covariances between traits and fitness. Evolution 46: 616-626.

RÉDEI, G. P. 1969. Arabidopsis thaliana (L.) Heynh., a review of the genetics and biology. Bibliographia Genetica 21: 1-151.

. 1992. A heuristic glance at the past of Arabidopsis genetics. In C. Koncz, N.-H. Chua, and J. Schell [eds.], Methods in Arabidopsis research, 1-15. World Scientific Publishing, Singapore.

REEKIE, E. G., AND F. A. BAZZAZ. 1987. Reproductive effort in plants. 1. Carbon allocation to reproduction. American Naturalist 129 : 876-896.

ROBERTSON, A. 1966. A mathematical model for the culling process in dairy cattle. Animal Production 8: 95-108.

Schlichting, C. D., AND M. PigliucCI. 1995. Gene regulation, quantitative genetics and the evolution of reaction norms. Evolutionary Ecology 9: 154-168.

Van Tienderen, P. H., AND G. DE Jong. 1994. A general model for the relation between phenotypic selection and genetic response. Journal of Evolutionary Biology 7: 1-12.

VĚTŘILOVÁ, M. 1973. Genetic and physiological analysis of induced late mutants of Arabidopsis thaliana. (L.) Heynh. Biologia Plantarum (Praha) 15: 391-397.

ViA, S, R. GomulKiewicz, G. DE Jong, S. M. Scheiner, C. D. SCHLichtING, AND P. H. VAN TIENDEREN. 1995. Adaptive phenotypic plasticity: consensus and controversy. Trends in Ecology and Evolution 10: 212-217.

Wallace, D. H., K. S. Yourstone, P. N. Masaya, and R. W. Zobel. 1993. Photoperiod gene control and partitioning between reproductive and vegetative growth. Theoretical and Applied Genetics 86: 6-16.

Watson, M. A. 1984. Developmental constraints: effect on population growth and patterns of resource allocation in a clonal plant. American Naturalist 123: 411-426.

-, AND B. B. CASPAR. 1984. Morphogenetic constraints on patterns of carbon distribution in plants. Annual Review of Ecology and Systematics 15: 233-258.

Westerman, J. M. 1971. Genotype-environment interaction and developmental regulation in Arabidopsis thaliana. IV. Wild material; analysis. Heredity 26: 383-395.

ZhANG, J., AND M. J. LeCHOwICZ. 1994. Correlation between time of flowering and phenotypic plasticity in Arabidopsis thaliana (Brassicaceae). American Journal of Botany 81: 1336-1342. 